\title{
URGENSI AKTA IKRAR WAKAF SEBAGAI ALTERNATIF PENYELESAIAN SENGKETA TANAH
}

\section{URGENCY OF WAQF PLEDGE CERTIFICATE AS AN ALTERNATIVE OF LAND DISPUTE RESOLUTION}

\author{
Rosdalina Bukido \\ Institut Agama Islam Negeri Manado, Faculty of Sharia, Institut Agama Islam Negeri Manado, \\ Sulawesi Utara, Indonesia, Jl. Dr. S.H. Sarundajang Kawasan Ring Road I Kota Manado, 95128 \\ Email: rosdalina.bukido@iain-manado.ac.id
}

\section{Misbahul Munir Makka}

Institut Agama Islam Negeri Manado, Faculty of Sharia, Institut Agama Islam Negeri Manado, Sulawesi Utara, Indonesia, Jl. Dr. S.H. Sarundajang Kawasan Ring Road I Kota Manado, 95128

Email:misbahulmakka66@gmail.com

Keywords:
Waqf, Dispute, Urgency of Waqf
Certificate

\begin{tabular}{l} 
ABSTRACT \\
\hline This paper was to identify the truth and position of waqf that occurred \\
in Bongkudai Village, East Bolaang Mongondow District, Indonesia and \\
to determine ways to resolve the problems that happened in the village. \\
There are problems regarding waqf land which is used for personal \\
interests and the issue of land payment receipts intended for waqf makes \\
the writer have the intention to prepare this study. The method used by \\
the author in the completion of this study was a qualitative method \\
whose approach is a descriptive approach, by prioritizing interviews and \\
field facts as the main source, for data collection conducted by the \\
author was observation, interviews, and documentation to get concrete \\
data and facts that occur in the field. The results obtained are that land \\
which is known as waqf land has been partly used for personal use. \\
Besides, there is a problem with the receipt in question. The land that is \\
known as waqf land should never be used for individual interests. A \\
receipt is actually not an urgent matter in a problem, as long as the \\
disputing party has no evidence to oppose it. Therefore it must be a land \\
payment receipt intended for waqf to directly record the endowment so \\
that problems do not occur in the future.
\end{tabular}

Kata kunci : ABSTRAK

Wakaf, Sengketa, Urgensi Akta Wakaf

\footnotetext{
Tulisan ini dibuat untuk mencari kebenaran dan kedudukan atas wakaf yang terjadi di Desa Bongkudai Kabupaten Bolaang Mongondow Timur, serta mencari cara untuk menyelesaikan permasalahan yang terjadi di Desa tersebut. Adanya permasalahan tentang tanah wakaf yang dipakai untuk kepentingan pribadi dan permasalahan kuitansi pembayaran tanah yang diniatkan untuk wakaf membuat penulis berniat untuk menyusun penelitian ini. Metode yang dilakukan oleh penulis dalam penyelesaian penelitian ini adalah dengan menggunakan metode kualitatif yang pendekatannya adalah pendekatan deskriptif, dengan mengutamakan wawancara dan fakta lapangan sebagai sumber utama, untuk pengumpulan data yang dilakukan oleh penulis adalah observasi, interviu dan dokumentasi untuk mendapatkan data yang konkrit dan fakta yang
} 
terjadi di lapangan. Hasil yang didapatkan adalah tanah diketahui sebagai tanah wakaf yang sebagiannya telah terpakai untuk digunakan demi kepentingan pribadi. Selain itu, ada permasalahan tentang sebuah kuitansi yang dipermasalahkan. Seharusnya tanah yang sudah diketahui adalah tanah wakaf jangan pernah dipakai untuk kepentingan seseorang belaka. Adapun sebuah kuitansi sebenarnya tidak menjadi hal yang urgen dalam sebuah permasalahan, selama pihak yang mempersengketakan tidak memiliki bukti untuk melawannya. Oleh karena itu, haruslah sebuah kuitansi pembayaran tanah yang diniatkan untuk wakaf langsung dilakukan pencatatan wakaf agar tidak terjadi permasalahan di kemudian hari.

Diterima: 13 Juni 2020; Direvisi: 27 Oktober 2020; Disetujui: 27 Oktober 2020; Tersedia online: 18 Desember 2020.

How to cite : Bukido, R., \& Makka, M. M. (2020). Urgensi Akta Ikrar Wakaf sebagai Alternatif Penyelesaian Sengketa Tanah. NUKHBATUL 'ULUM: Jurnal Bidang Kajian Islam, 6 (2), 244-257. https://doi.org/10.36701/nukhbah.v6i2.161

\section{PENDAHULUAN}

Berbicara persoalan Islam dan juga ekonomi, sebenarnya tidak hanya membicarakan persoalan kemajuan atau kemunduran kehidupan yang dialami oleh salah satu pihak (golongan agama) tertentu, melainkan turut membicarakan persoalan kemanusiaan dan kesejahteraan yang lebih luas ${ }^{1}$.

Salah satu langkah kesejahteraan ekonomi adalah wakaf. Menurut Ridwan Jamal, wakaf adalah salah satu ibadah yang dilakukan dengan cara menyisihkan sebagian harta yang dimiliki untuk dijadikan sebagai harta milik umum yang dapat dimanfaatkan untuk kepentingan orang lain atau banyak orang. Ia adalah lembaga keamanan yang dianjurkan Allah swt. untuk dijadikan sebagai sarana penyaluran harta yang dikaruniakan olehnya kepada manusia ${ }^{2}$. Menurut Ahmad Suwaidi wakaf menjadi salah satu bidang yang bisa membantu mesejahterakan rakyat Indonesia, terutama masyarakat beragama Islam di Indonesia. Sejak dahulu wakaf di negara modern, bahkan jauh pada kesultanan pada masa lalu, telah memainkan peran yang penting dalam meningkatkan kesejahteraan pada masyarakat ${ }^{3}$. Dengan demikian, wakaf sendiri merupakan salah satu ibadah yang dapat mencakup hubungan dengan Allah swt. dan hubungan dengan manusia itu sendiri.

Sepanjang sejarah Islam, wakaf merupakan sarana modal yang penting dalam memajukan perkembangan agama. Tanah wakaf mempunyai fungsi fundamental dalam membantu kesejahteraan, pembangunan dan kemajuan

${ }^{1}$ Ahmad Djunaidi and Thobieb Al-Asyhar, Menuju Era Wakaf Produktif(Depok: Mumtaz Publishing, 2007). h. 3.

${ }^{2}$ Ridwan Jamal, 'Hukum Perwakafan Kompilasi Hukum Islam Dalam Sorotan', Jurnal Ilmiah Al-Syir'ah, 6.1 (2008). h. 1-2.

${ }^{3}$ Ahmad Suwaidi, 'Wakaf Dan Penerapannya Di Negara Muslim', Economic: Jurnal Ekomomi Dan Hukum Islam, 1.2 (2011), 14-33. h. 14. 
masyarakat ${ }^{4}$. Menurut Abdul Manan, praktik wakaf yang dilaksanakan di Indonesia masih dilaksanakan secara konvensional yang memungkinkan rentan terhadap berbagai masalah dan tidak sedikit yang berakhir di pengadilan. Kondisi ini diperparah lagi dengan adanya penyimpangan terhadap benda-benda wakaf yang dilakukan oleh oknum yang tidak bertanggung jawab, dan sudah menjadi rahasia umum bahwa ada benda-benda yang dapat diperjualbelikan ${ }^{5}$. Dengan demikian, sering terjadi konflik mengenai perwakafan dalam hal ini dikarenakan berkaitan mengenai harta.

Berbicara ihwal konflik yang sudah merupakan sesuatu yang tidak terpisahkan dalam masyarakat dan akan selalu menjadi masalah yang serius apabila tidak dapat diselesaikan serta akan selalu mengakibatkan hilangnya keseimbangan atau kedamaian dalam masyarakat ${ }^{6}$. Konflik sosial masyarakat dan adanya tuntutan kesejahteraan ekonomi, membuat wakaf menjadi hal yang sangat urgen untuk direalisasikan. Selain dilihat sebagai salah satu ajaran dalam Islam, wakaf juga mengandung makna penting untuk kesejahteraan ekonomi. Oleh karena itu, wakaf ini tidak bisa disepelekan dan diabaikan di kehidupan bermasyarakat.

Wakaf sebagai lembaga kebajikan dan amanah (charity and trust) dalam Islam tidaklah terlepas dari dimensi sosial, dan memang implikasinya adalah untuk kesejahteraan sosial. Berbicara tentang kesejahteraan, maka kita tidak bisa terlepas dari suatu nilai, baik nilai spiritual maupun nilai sosial terlebih nilai ekonomis. Dalam masyarakat kontemporer, adanya proses sosial yang mana kompetisi terhadap suatu nilai merupakan bagian dari proses sosial itu sendiri. Ketika kompetisi menjadi intens, maka kecenderungannya akan berlanjut pada kondisi di mana masyarakat akan mengalami eskalasi yang menjadi sengketa (dispute). Dengan demikian, dalam sejarah hukum Islam, ternyata masyarakat muslim tidak dapat terhindar dari proses sosial tersebut, sehingga sumber nilai yang ada pada wakaf telah menggerakkan tindakan mereka dalam berkompetisi dan muncul menjadi sengketa perwakafan dalam masyarakat muslim (moslem society) ${ }^{7}$.

Perwakafan dalam bidang tanah di Indonesia juga merupakan salah satu bidang dalam hukum agraria yang mana mengatur tentang pengaturan dari penggunaan dan pemanfaatan sumber daya alam yang mencakup bumi air dan luar angkasa demi mensejahterakan rakyat Indonesia. Untuk itu, wakaf

${ }^{4}$ Rahmad Djamika, Tanah Wakaf(Surabaya: Al-Ikhlas, 1983). h. 31.

${ }^{5}$ Abdul Manan, Aneka Masalah Hukum Perdata Di Indonesia (Jakarta: Kencana, 2008). h. 235.

${ }^{6}$ Ibrahim Siregar, 'Penyelesaian Sengketa Wakaf Di Indonesia', MIQOT, 36.1 (2012). h. 123.

${ }^{7}$ Ibrahim Siregar, 'Penyelesaian Sengketa Di Indonesia: Pendekatan Sejarah Sosial Hukum Islam’, MIQOT: Jurnal Ilmu-IImu Keislaman, 13.1 (2012). h. 136. 
merupakan salah satu aset yang harus dijaga kemurniannya, sehingga tanah wakaf tersebut tidak boleh dijual, diwariskan dan dihibahkan atau mungkin dipindahtangankan melalui cara lain melawan hukum. Dengan demikian, seorang nazir yang telah diamanahkan haruslah dengan profesional dalam memelihara aset wakaf tersebut agar tidak terjadi sengketa untuk aset tersebut.

Pada persoalan wakaf ini, sebenarnya gejala awalnya dimulai dengan sebidang tanah yang diwakafkan oleh pemilik tanah pada tahun 1983 M., yang diniatkan untuk kepentingan umat Islam di Desa Bongkudai. Singkatnya, selanjutnya dibentuklah tim untuk didiskusikan pembangunan yang paling urgen di Desa Bongkudai dan dibuatlah Madrasah Ibtidaiyah (MI). Pada tanah wakaf tersebut, tersisa sedikit dari tanah (space) untuk pembangunan MI, sehingga tanah itu dijadikan sebagai akses jalan masuk. Namun, karena di sekitar rumah salah satu warga yang dalam tahap pembangunan, maka sekonyong-konyong warga itu dengan sadarnya mengambil tanah tersebut untuk dijadikan sebagai haknya dalam membangun rumahnya. Awalnya, ada sedikit tanah yang dibeli sebagai tambahan tanah untuk akses jalan masuk. Namun, pembelian tanah itu juga dipersengkatan walaupun ada kuitansi pembayaran atas tanah tersebut dan selanjutnya diambil serta tanah sisa wakaf itu.

Berkenaan berbagai permasalahan tentang wakaf yang terjadi di Indonesia (semisal fenomena di atas), maka pemerintah mengeluarkan peraturan dalam Peraturan Pemerintah No. 28 Tahun 1977 Tentang Perwakafan Tanah Milik dengan tujuan untuk membebaskan perwakafan dari segala ikatan, sitaan, dengan menjaminkan manfaatnya. Selanjutnya, diatur pula dalam Undang-Undang Nomor 41 Tahun 2004 Tentang Wakaf. Peraturan ini menegaskan mengenai segala perbuatan perwakafan harus dicatat dalam sebuah Akta Ikrar Wakaf (AIW), sehingga perwakafan yang terjadi di Indonesia dapat dijamin keamanannya dan dapat diperoleh manfaatnya.

Atas fakta sosial di atas, maka penulis bermaksud untuk meneliti masalah yang terjadi di wilayah tersebut dari segi pentingnya akta wakaf ketika pewakaf ingin mewakafkan hartanya. Adapun agar penelitian ini dapat terarah dan tidak menimbulkan kesalahan interpretasi, maka peneliti merumuskan masalah penelitian, yakni: (1) Bagaimana peran akta wakaf untuk mengantisipasi permasalahan sengketa yang terjadi di Desa Bongkudai Kecamatan Modayag Kabupaten Bolaang Mongondow Timur?; (2) Bagaimana solusi penyelesaian masalah sengketa tanah yang terjadi di Desa Bongkudai Kecamatan Modayag Kabupaten Bolaang Mongondow Timur?

Tujuan dari penelitian ini yaitu untuk mengetahui peran dari akta wakaf sehingga dikatakan sangat penting dan harus ada sebagai pengantisipasi permasalahan sengketa wakaf yang terjadi di Desa Bongkudai, Kabupaten Bolaang Mongondow Timur. Selain itu, tujuan lainnya ialah untuk memberikan 
solusi yang baik terhadap penyelesaian sengketa yang tejadi di Desa Bongkudai, Bolaang Mongondow Timur.

Penelitian yang dilakukan oleh penulis adalah berjenis penelitian kualitatif. Dalam penelitian kualitatif ini, penulis bermaksud untuk memahami fenomena tentang apa yang dialami oleh subjek penelitian, misalnya, persepsi, pandangan, motivasi dan tindakan sehari-hari secara holistik dan dengan metode depenelitian dalam bentuk kata-kata dan bahasa naratif pada suatu konteks khusus yang alamiah dan dengan mamanfaatkan berbagai metode alamiah. Adapun teknik pengumpulan data dengan menggunakan interviu, observasi lapangan, dan studi dokumentasi.

Terdapat pula beberapa penelitian yang memiliki keterkaitan dengan penelitian penulis. Pertama, penelitian tentang "Analisis Terhadap Sertifikasi dalam Sengketa Tanah Wakaf (Studi Kasus Mushola Nurun Nafi' di Jalan Kintelan Kelurahan Bendugan Kecamatan Gajah Mungkur Kota Bandung)" oleh Hazian Aulia Magnesi pada tahun 2018 M. Tujuan dari penelitian ini yaitu untuk mengetahui penyebab sengketa tanah wakaf Mushola Nurun Nafi' di Jalan Kintelan Kelurahan Bendungan Kecamatan Gajan Mungkur Kota Bandung. Hasil penelitian yaitu status tanah wakaf yang dipersengketakan ialah dikarenakan belum adanya sertifikat tanah wakaf yang sah dari pihak BPN. Hal ini disebabkan oleh kelebihan tanah wakaf pada saat musholla tersebut didirikan. Selain itu, kurangnya komunikasi yang baik antara pihak wakif, nazir, takmir dan dan warga sekitar dan pembangunan musala. Adapun agar sertifikat tanah jelas, maka harus segera dibagi menjadi dua bagian yaitu pertama milik wakif dan bagian kedua milik Mushola Nurun Nafi' yang kemudian didaftarkan secara sah kepada pihak BPN ${ }^{8}$.

Kedua, penelitian tentang "Problematika Tanah Wakaf yang Tidak Memiliki Akta Ikrar Wakaf (Studi di Desa Kotaway Kecamatan Buay Pemaca Kabupaten Ogan Komering Selatan)" oleh Zelania pada tahun 2017 M. Tujuan dari penelitian ini ialah untuk mengetahui permasalahan tanah wakaf yang tidak memiliki Akta Ikrar Wakaf (AIW) di Desa Kotaway Kecamatan Buay Pemaca Kabupaten Ogan Komering. Hasil penelitiannya yakni problematika tanah wakaf yang terjadi di Desa Kotaway lantaran penjualan pada sebagian tanah wakaf dan pemanfaatannya untuk kepentingan pribadi ${ }^{9}$. Hal tersebut dikarenakan tidak

${ }^{8}$ Hazian Aulia Magnesi, 'Analisis Terhadap Sertifikasi Dalam Sengketa Tanah Wakaf (Studi Kasus Mushola Nurun Nafi' Di Jalan Kintelan Kelurahan Bendugan Kecamatan Gajah Mungkur Kota Bandung)' (Fakultas Syariah dan Hukum, Universitas Islam Negeri Walisongo, 2018).

${ }^{9}$ Zelania, 'Problematika Tanah Wakaf Yang Tidak Memiliki Akta Ikrar Wakaf (Studi Di Desa Kotway Kecamatan Buay Pemaca Kabupaten Ogan Komering Selatan)’ (Institut Agama Islam Negeri Metro, 2017). 
adanya Akta Ikrar Wakaf (AIW) sehingga tidak adanya kekuatan hukum terhadap tanah wakaf tersebut.

Beberapa penelitian di atas memiliki persamaan dengan penelitian yang dilakukan oleh penulis, yaitu meneliti tentang permasalahan sengketa wakaf. Penelitian Zelania menunjukkan bahwa terjadi pengelolaan wakaf hanya untuk kepentingan pribadi, sama halnya dengan yang terjadi di Desa Bongkudai, hanya saja bukan menjual tanah wakaf tersebut melainkan dibangun sebuah bangunan dan menghambat akses masuk ke dalam madrasah. Penelitian dari Haizan Aulia Pangesti juga menunjukkan bahwa permasalahan wakaf disebabkan oleh karena tidak adanya sertifikat wakaf, ini sama halnya di Desa Bongkudai dengan masalah yang serupa. Namun, berbeda dengan penelitian yang kedua yang meneliti tentang permasalahan yang terjadi. Dengan demikian, cara menyelesaikan permasalahan tersebut, maka penulis berikhtiar mengkaji akan pentingnya Akta Ikrar Wakaf (AIW) sebagai bentuk pencegahan berbagai permasalahan-permasalahan wakaf di masyarakat.

\section{PEMBAHASAN}

\section{Persoalan Wakaf Pada Umumnya}

Wakaf mengandung pengertian sebagai sebuah pemberian untuk penahanan harta, sehingga harta tersebut sudah bukan menjadi milik pribadi melainkan menjadi milik Allah swt. untuk diambil manfaatnya demi kepentingan orang banyak. Habibi mengungkapkan bahwa wakaf adalah mempersembahkan suatu harta yang bisa diambil manfaatnya dengan tetap seutuhnya sebagai materi benda untuk tujuan yang legal dengan memutus rantai perpindahan hak milik ${ }^{10}$.

Dalam sejarah Islam, amal wakaf yang telah dilakukan oleh para sahabat Nabi saw., seperti yang dilakukan oleh Umar yang berupa tanah di Khaibar, kemudian disusul oleh Abu Thalhah yang mewakafkan kebun kesayangannya yaitu Bairoha. Selanjutnya disusul oleh sahabat lainnya, 1) Abu Bakar ashSiddiq, 2) Usman bin Affan, 3) Ali bin Abi Thalib, 4) Anas bin Malik, 5) Abdullah bin Umar, 6) Zuber bin Awam dan 7) Aisyah isteri Rasulullah Saw. kemudian diikuti oleh seluruh umat Islam yang ada di dunia ${ }^{11}$.

Dalam menyoal problematika wakaf yang terjadi, Undang-Undang Nomor 41 Tahun 2004 telah menyatakan bahwa ada dua jalur penyelesaian sengketa wakaf yaitu jalur litigasi dan non litigasi, yaitu melalui jalur Pengadilan Agama dan untuk jalur non litigasi yaitu musyawarah. Pada Pasal 62 Undang-Undang Nomor 41 Tahun 2004 juga menyatakan bahwa penyelesaian sengketa perwakafan ditempuh melalui musyawarah untuk mufakat, apabila penyelesaian

${ }^{10}$ M. Habibi, Fiqih Wakaf, Dalam Pandangan Empat Mazhab Dan Problematikanya (Kediri: Santri Salaf Press, 2017). h.19.

${ }^{11}$ Suparman Usman, Hukum Perwakafan Di Indonesia (Jakarta: Darul Ulum, 1999). h. 27. 
sengketa tidak berhasil, dapat diselesaikan melalui mediasi, arbitrase atau pengadilan ${ }^{12}$.

Peraturan Pemerintah Republik Indonesia Nomor 42 Tahun 2006 Tentang Pelaksanaan Undang-Undang Nomor 41 Tahun 2004 Tentang Wakaf menjelaskan bahwa Akta Ikrar Wakaf, yang selanjutnya disingkat AIW adalah bukti pernyataan kehendak wakif untuk mewakafkan harta benda miliknya guna dikelola oleh nazir yang sesuai dengan peruntukan harta benda wakaf yang dituangkan dalam bentuk akta.

Legitimasi dari adanya akta wakaf dapat dilihat dari pasal 17 (2) UndangUndang Nomor 41 Tahun 2004 Tentang Wakaf bagian ikrar wakaf bahwasannya, ikrar wakaf dinyatakan secara lisan/tulisan serta dituangkan dalam Akta Ikrar Wakaf oleh PPAIW. Akta Ikrar Wakaf atau biasa disebut Akta Wakaf adalah salah satu akta yang termasuk dalam bentuk akta otentik karena dibuat oleh pejabat yang diberi wewenang akan hal tersebut. Hal ini telah sesuai dengan Pasal 1868 Kitab Undang-Undang Hukum Perdata, yaitu "Suatu akta otentik ialah suatu akta dalam bentuk yang ditentukan oleh undang-undang, dibuat oleh atau dihadapan kepada pegawai-pegawai umum yang berkuasa untuk itu di tempat atau di mana akta dibuatnya."

Kebenaran yang ada dalam akta otentik mengikat para pihak, dan mengikat kepada hakim, sehingga hakim harus menjadikannya sebagai fakta yang sempurna dan cukup untuk mengambil keputusan. Melekatnya keputusan pembuktian yang sempurna dan mengikat akta otentik membuat dirinya mampu berdiri sendiri sebagai bukti, dia tidak memerlukan bantuan alat bukti lain, sehingga batas minimal pebuktiannya cukup pada dirinya sendiri ${ }^{13}$.

\section{Kedudukan Tanah Wakaf Madrasah Ibtidaiyah Negeri 1 Bongkudai}

Saat ini cukup banyak masyarakat yang memahami bahwa benda yang dapat diwakafkan hanyalah benda tidak bergerak seperti tanah, bangunan dan benda-benda tidak bergerak lainnya. Dengan demikian, peruntukannya pun sangat terbatas, seperti untuk masjid, musala, rumah yatim piatu, madrasah, sekolah dan sejenisnya. Pada umumnya masyarakat mewakafkan tanahnya untuk dibangun masjid, karena masjid dipergunakan untuk beribadah. Walaupun wakaf untuk masjid penting, namun jika masjid sudah banyak, akan lebih manfaat jika wakif mewakafkan hartanya untuk hal-hal yang lebih produktif. Dalam hal wakif yang kurang mempertimbangkan kemampuan nazir untuk mengembangkan masjid, maka masjid menjadi pusat kegiatan. Dengan demikian, wakaf yang ada,

${ }^{12}$ T. O. Ihroni, Antropologi Hukum: Sebuah Bangsa Rampai (Jakarta: Yayasan Obor Indonesia, 2001). h. 212.

${ }^{13}$ Adnan Qohar, Tanya Jawab, Hukum Pembuktian Dalam Teori Dan Praktik (Yogyakarta: Pustaka Biru, 2011). h.29 
hanya terfokus untuk memenuhi kebutuhan peribadatan, dan sangat sedikit wakaf yang berorientasi untuk meningkatkan perkonomian umat ${ }^{14}$.

Temuan yang didapatkan adalah Tim Bina Utama pada saat itu melakukan musyawarah tentang peruntukan tanah wakaf tersebut dan disimpulkan bahwa untuk tanah tersebut diperuntukan dalam membangun sekolah dasar berbasis Islam. Jika tanah wakaf itu dibangun masjid, maka di Desa Bongkudai sudah memiliki masjid. Selain itu, mengingat juga keinginan dari wakif supaya digunakan untuk kepentingan umat Islam, sehingga dijadikanlah sebuah madrasah yang berbasis Ibtidaiyah.

Berdasarkan kesaksian dan bukti yang berbentuk akta pada Madrasah Ibtidaiyah Negeri Bongkudai, bahwa benar madrasah tersebut adalah madrasah yang dibangun dari sebuah tanah wakaf, yang di mana juga ada sisa tanah wakaf yang dijadikan sebagai jalur akses masuk ke madrasah yang memiliki lebar 1,5 meter. Dengan demikian, tanah tersebut bukan tanah yang dimiliki oleh siapaun melainkan sudah menjadi milik Allah swt. dan tidak boleh diganggu oleh pihak manapun walaupaun hanya sejengkal saja.

Melihat pada bukti akta wakaf yang ditunjukkan, tanah wakaf tersebut tercatat sebagai sebuah wakaf yang diperuntukkan untuk membangun madrasah. Hanya dengan menggunakan dana dari warga setempat pada awal pembangunan madrasah tersebut dan dilanjutkan menggunakan dana dari Departemen Agama Kecamatan Modayag dengan membuat sertifikat tanah wakaf tersebut. Selain itu, untuk pembangunan tersebut, masih terdapat sisa tanah yang akan dibuat sebagai akses masuk ke madrasah.

Apabila memperhatikan ketentuan Pasal 9 Ayat 5 Peraturan Pemerintah Nomor 28 Tahun 1977, tersirat bahwa Akta Ikrar Wakaf merupakan akta otentik yang dapat dipergunakan dalam penyelesaian sengketa yang mungkin timbul dikemudian hari tentang tanah yang diwakafkan. Dengan perkataan lain, Akta Ikrar Wakaf merupakan alat bukti atas pelaksanaan wakaf sekaligus menerangkan status tanah wakafnya ${ }^{15}$. Dengan demikian, tanah tersebut sudah memiliki kekuatan penuh dari hukum yang berlaku dan bisa dijadikan bukti yang konkret jika ada yang ingin mempersoalkan atau mengganggu atas tanah tersebut.

Demi tercapainya perwakafan yang terlaksana dengan baik, ada beberapa strategi yang mesti dilakukan: (1) Penyuluhan secara kontinu; (2) Meningkatkan peran dan fungsi wakaf; (3) Mengadakan atau meningkatkan koordinasi dengan lembaga sosial yang ada; (4) Meningkatkan peran dan fungsi serta koordinasi

${ }^{14}$ Uswatun Hasanah, 'Urgensi Pengawasan Dalam Pengelolaan Wakaf Produktif Di Indonesia', Al-Ahkam: Jurnal Pemikiran Hukum Islam, 22.1 (2012). h. 68

${ }^{15}$ Upi Komariah, 'Penyelesaian Sengketa Wakaf Di Pengadilan Agama', Jurnal Hukum Dan Peradilan, 3.2 (2014). h. 121. 
Kandepag di setiap tingkat II; (5) Merealisir pencatatan, pengangkatan tanah wakaf; (6) Penataran pejabat dan nazir; (7) Evaluasi dan pembenahan pengurus atau nazir; (8) Pertemuan berkala antar kecamatan; (9) Nazir atau pejabat wakaf harus punya program kerja baik untuk jangka pendek dan jangka panjang; dan (10) Nazir harus punya pendidikan dan orang yang paham tentang wakaf dan upaya-upaya yang mesti dilakukannya ${ }^{16}$.

\section{Penyelesaian Sengketa}

Apabila terjadi permasalahan dalam sengketa harta wakaf ini, maka penyelesaian sengketa dapat dilakukan melaui musyawarah untuk mencapai kata mufakat. Apabila hal tersebut tidak berhasil diselesaikan, maka dapat menggunakan bantuan pihak ketiga, yaitu mediasi, arbitrase syariah atau Pengadilan Agama ${ }^{17}$. Hal ini seesuai dalam Undang-undang Nomor 41 Tahun 2004 tentang wakaf bahwa penyelesaian sengketa perwakafan ditempuh melalui musyawarah untuk mencapai mufakat. Namun, apabila penyelesaian sengketa tidak berhasil, sengketa dapat diselesaikan melalui mediasi, arbitrase atau pengadilan ${ }^{18}$.

Perihal di atas, dengan merujuk pada tulisan Ismawati ${ }^{19}$, dijelaskannya bahwa metode penyelesaian sengketa yang terjadi di Wilayah Jawa Tengah Bagian Utara ada dua jalur, yaitu jalur lititgasi dan non litigasi. Jalur non litigasi merupakan alternatif penyelesaian sengketa di luar Pengadilan. Para pihak menganggap bahwa mekanisme penyelesaian sengketa non litigasi adalah upaya awal dalam penyelesaian sengketa, hal ini meliputi: (1) Musyawarah yaitu penyelesaian sengketa dari para pihak yang terlibat sengketa, melalui proses atau kegiatan yang saling mendengar, menerima pendapat dan keinginan yang didasarkan atas kesukarelaan di antara para pihak; (2) Mediasi adalah penyelesaian sengketa melalui proses perundingan para pihak dengan dibantu oleh mediator.

Jalur litigasi adalah model penyelesaian sengketa wakaf melalui proses hukum dalam acara di Peradilan Agama yang di mana produk hukum Hakim Pengadilan adalah: (1) Akta Perdamaian, jika penyelesaian sengketa wakaf melalui mediasi Pengadilan Agama; (2) Putusan Hakim Peradilan Agama, jika penyelesaian sengketa sudah melalui hukum acara yang sudah diputuskan oleh Hakim Peradilan Agama. Dengan demikian, penyelesaian secara musyawarah

\footnotetext{
${ }^{16}$ Abdul Halim, Hukum Perwakafan Di Indonesia (Ciputat: Ciputat Press, 2005). h. 112113.

${ }^{17}$ Elsi Kartika Sari, Pengantar Hukum Zakar Dan Wakaf(Jakarta: Grasindo, 2007). h. 78.

18 Departemen Agama RI, Fiqih Wakaf (Jakarta: Direktorat Jenderal Bimbingan Masyarakat Islam, 2007). h. 84.

${ }^{19}$ Ismawati and Et.al, 'Implementasi UU Wakaf Dalam Penyelesaian Sengketa Wakaf Di Wilayah Pesisir Jawa Tengah', Jurnal Masalah-Masalah Hukum, 48.4 (2019), 331-40. h. 337.
} 
merupakan penyelesaian sengketa dari para pihak yang terlibat dalam sengketa, yang diawali dengan mendengarkan keluhan pihak yang merasa dirugikan, kemudian dijawab oleh pihak lain yang menyebabkan sengketa wakaf terjadi. Penyelesaian dengan cara ini merupakan penyelesaian yang mudah, sederhana, murah dan terjamin kerahasiaannya. Penyelesaian sengketa wakaf dengan musyawarah biasanya terjadi pada masalah sederhana, karena para pihak mempunyai daya toleransi tinggi untuk menyatukan atau mencari persamaan dari perbedaan pendapat demi terselesaikannya sengketa wakaf, sehingga menimbulkan hubungan baik pasca sengketa.

Berkaitan dengan yang terjadi di lokasi penelitian, walaupun musyawarah telah ditempuh, faktanya, sengketa wakaf tersebut sampai sekarang masih belum bisa diselesaikan, jika melihat dari cara penyelesaian sengketa wakaf yang terjadi di wilayah Jawa Tengah, maka langkah selanjutnya jika masih belum bisa diselesaikan adalah dengan mengajukannya di Pengadilan dan dari Pengadilan inilah yang akan melakukan mediasi untuk awalnya, dan jika sengketa wakaf tersebut masih belum bisa diselesaikan juga, maka Majelis Hakim dapat memberikan putusan dan itu adalah sifatnya mutlak. Namun, sebelum mencapai pada tahap akhir yaitu di Pengadilan, alangkah baiknya untuk menempuh jalur perdamaian. Perdamaian ini sangat penting apalagi yang bersengketa masih memiliki hubungan keluarga dekat, dalam hal ini masih menjadi masyarakat di tempat yang sama pula, dengan melakukan perdamaian akan bisa lebih mendekatkan dan juga bisa merajut kembali hubungan yang retak menjadi lebih baik lagi.

\section{Keharusan Pengadaan Akta Ikrar Wakaf}

Harta wakaf pada prinsipnya adalah milik umat, dengan demikian manfaatnya juga harus dirasakan oleh umat dan oleh karena itu pada tataran idealnya, maka harta wakaf adalah tanggung jawab kolektif guna menjaga keeksisannya. Untuk itu, keberadaan lembaga yang mengurusi harta wakaf mutlak diperlukan sebagaimana yang telah dilakukan oleh sebagian negaranegara Islam. Indonesia masih terkesan lamban dalam mengurusi wakaf sekalipun mayoritas penduduknya beragama Islam. Implikasinya menyebabkan banyaknya harta-harta wakaf yang kurang terurus dan bahkan masih ada yang belum dimanfaatkan ${ }^{20}$.

Wakaf yang telah dimanfaatkan untuk sarana pendidikan memerlukan keterlibatan semua elemen masyarakat dalam merawatnya. Agar Madrasah Ibtidaiyah Bongkudai tetap aman dan bisa diambil fungsinya, maka dari aspek administrasi perwakafan harus baik dan terawat bangunannya yang otentik.

\footnotetext{
${ }^{20}$ Komariah, ' Penyelesaian Sengketa Wakaf di Pengadilan Agama'. h. 118.
} 
Upaya ini perlu usulan (buttom up) dari pengurus madrasah atau pemerintah dalam meresponnya (top down). Dengan demikian, melindungi harta yang berasal dari wakaf merupakan wujud kesadaran yang tinggi dari generasi masa kini yang memanfaatkan benda wakaf.

Dalam hal pembelian untuk wakaf, uang yang dikumpulkan dari beberapa orang, dalam rangka tanah tersebut yang mana akan dijadikan masjid, jika telah dibelikan tanah, maka menurut salah satu pendapat dalam mazhab syafii akan langsung menjadi tanah wakaf sekaligus menjadi masjid. Pendapat ini adalah pendapat Syaikh Abu Muhammad. Seandainya uang tersebut digunakan untuk membeli tanah yang akan diwakafkan menjadi masjid maka tanah yag dibeli langsung menjadi masjid tanpa perlu sḥigah wakaf dari salah satu penyumbang. Adapun model yang hendak diterapkan pada tanah tersebut disesuaikan dengan 'urf muttarid di daerah tanah tersebut berada. Seandainya tanah yang berlaku adalah menjadikan tanah menjdi masjid dan sebagian menjadi serambi (rahbah) serta fasiitas pendukung, seperti toilet, tempat sampah dan lain-lain, maka tanah tang berstatus masjid adalah tanah yang nantinya ditanami bangunan masjid dan selainnya bukan. Bila kebiasaannya berbeda dengan itu maka disesuaikan ${ }^{21}$.

Kasus ini serupa dengan yang terjadi di lokasi penelitian, namun peruntukannya untuk dibuatkan jalan akses masuk ke madrasah. Untuk itu, dengan melihat dari pandangan di atas, maka tanah tersebut dikatakan sebagai tanah wakaf. Namun, ada catatannya, menurut As-Subki, aset yang tidak langsung menjadi wakaf akan menjadi wakaf dan butuh ikrar wakaf dari orang yang mewakili ${ }^{22}$.

Beberapa hal yang akan terjadi jika sengketa tanah wakaf tersebut tidak bisa diselesaikan: (1) Anak-anak yang bersekolah di sana terpaksa harus mencari jalan yang lain dan jalan yang lain itu memiliki risiko yang besar bagi anak-anak tersebut, jika tanah tersebut dibangun sebuah bangunan, maka untuk jalur akses masuk ke dalam madrasah akan tersendat dan bahkan sudah tidak bisa dilalui lagi, sehingga para siswa terpaksa harus pergi ke madrasah dengan melalui jalur yang lain dan jalur tersebut diketahui adalah jalur yang terjal dan sulit untuk dilalui oleh para siswa yang kemungkinan berdampak buruk kepada mereka; (2) Dengan melihat kesulitan para siswa untuk pergi ke madrasah dan para orang tua tidak ingin anak meraka terjadi hal yang tidak mereka inginkan, maka kemungkinan besar orang tua akan memindahkan anaknya ke sekolah yang lain; (3) Jika masalah ini tidak bisa terselesaikan kemungkinan terbesarnya adalah perseteruan yang akan berkelanjutan.

\footnotetext{
${ }^{21}$ Habibi, Fiqih Wakaf dalam Pandangan Empat Mazhab dan Problematikanya. h. 134.

${ }^{22}$ Habibi, Fiqih Wakaf dalam Pandangan Empat Mazhab dan Problematikanya. h. 234.
} 
Selain berdampak kepada masyarakat, hal ini juga akan berdampak kepada pemerintah, khususnya kepada Petugas Pencatat Akta Ikrar Wakaf (PPAIW) karena bisa dikenakan sanksi administratif. Pada Pasal 68 UndangUndang Nomor 41 Tahun 2004, Menteri dapat mengenakan sanksi administratif atas pelanggaran tidak didaftarkan harta benda wakaf oleh PPAIW. Kemudian sanksi administratif tersebut menurut Pasal 68 Undang-Undang Nomor 41 Tahun 2004 berupa; peringatan tertulis, penghentian sementara atau pencabutan izin kegiatan di bidang wakaf dan penghentian sementara dari jabatan atau penghentian dari jabatan PPAIW ${ }^{23}$. Oleh karena itu, berlakunya Undang-Undang Nomor 41 Tahun 2004 tentang Wakaf, maka pencatatan perbuatan hukum wakaf adalah wajib, sehingga apabila saat ini masih ada tanah atau barang-barang wakaf yang ikrar wakafnya belum dicatatkan, maka haruslah segera dicatatkan.

Hal itu dimaksudkan untuk memberikan perlindungan akan urgensi pencatatan wakaf di Indonesia setelah berlakunya hukum, dan kepastian hukum bagi wakif, nazir dan harta yang diwakafkan, serta menghindari munculnya sengketa wakaf dikemudian hari. Dalam hal ini tanah yang awalnya dibeli untuk diniatkan sebagai wakaf haruslah dicatat sebagai tanah wakaf oleh pencatat wakaf agar menghindari segala sesuatu yang tidak diinginkan di kemudian hari. Dengan demikian, perlindungan atau pengamanan tanah wakaf baik suka maupun tidak suka, maka haruslah didahului dengan penyadaran kepada masyarakat akan pentingnya sebuah akta ikrar wakaf. Urgensinya adalah dilihat dari sengketa tanah wakaf dapat terjadi sewaktu-waktu, apalagi dalam masyarakat yang tidak paham hukum. Masyarakat tampak berkecenderungan dalam meremehkan akta ikrar wakaf, padahal hal itu akan berdampak buruk bagi perkembangan pengelolaan tanah wakaf.

\section{KESIMPULAN}

Untuk status tanah yang dipersengketakan adalah tanah yang memiliki bukti yang kuat walaupun dibawa ke Pengadilan. Akta wakaf memiliki kekuatan dalam hal pembuktian jika terjadi permasalahan yang terjadi di kemudian hari, terkhusus pada apa yang terjadi di Desa Bongkudai yaitu Madrasah Ibtidaiyah Negeri Bongkudai. Walaupun ada yang dengan sengaja atau tidak sengaja menyentuh atau mengambil tanah yang berstatus wakaf. Hanya saja untuk akta tersebut tidak dapat dikeluarkan dari Kantor Urusan Agama (KUA). Untuk itu, seorang nazir harus membuatkan kata tersebut di Kantor Urusan Agama.

Ada beberapa hal yang terjadi di Desa Bongkudai yang masih bisa diselesaikan dengan kekeluargaan dalam artian masih bisa di musyawarakan dan untuk status tanah yang dipersengketakan adalah tanah yang memiliki bukti yang

${ }^{23}$ Sari, Pengantar Hukum Zakar dan Wakaf. h. 80 
kuat walaupun dibawa ke Pengadilan. Demi kemaslahatan bersama, alangkah baiknya ini bisa diselesaikan dengan cara mufakat atau untuk menciptakan terjadinya perdamaian, dari pihak yang membeli tanah tersebut diharapkan dapat membeli kembali tanah itu demi terselesainya permasalahan yang berkepanjangan.

Pengharapan itu ditujukan kepada Kantor Urusan Agama, karena ia memiliki kewenangan dan kewajiban mengenai ibadah wakaf seseorang, yang mana seharusnya bisa lebih memperhatikan perwakafan yang dilakukan oleh seseorang. Wakaf merupakan salah satu hal yang mampu mensejahterahkan umat dan juga perlu diperhatikan oleh pemerintah. Alangkah baiknya jika Kantor Urusan Agama (KUA) menaruh perhatian yang lebih terhadap perwakafan ini. Adapun, kepada pihak sekolah ataupun nazir untuk membuat akta ikrar wakaf di Kantor Urusan Agama agar mendapat legitimasi yang kuat. Jika permasalahan ini masih belum bisa diselesaikan dengan musyawarah, maka baiknya permasalahan ini dibawa ke Pengadilan. Adapun jika permasalahan ini sudah selesai, alangkah baiknya bila tanah itu dibuat sebagai tanah wakaf yang diikrarkan agar kekuatan hukumnya bisa lebih terjaga.

\section{DAFTAR PUSTAKA}

Djamika, R. (1983). Tanah Wakaf. Al-Ikhlas.

Djunaidi, A., \& Al-Asyhar, T. (2007). MENUJU Era Wakaf Produktif. Mumtaz Publishing.

Habibi, M. (2017). Fiqih Wakaf, dalam Pandangan Empat Mazhab dan Problematikanya. Santri Salaf Press.

Halim, A. (2005). Hukum Perwakafan di Indonesia. Ciputat Press.

Hasanah, U. (2012). Urgensi Pengawasan Dalam Pengelolaan Wakaf Produktif di Indonesia. Al-Ahkam: Jurnal Pemikiran Hukum Islam, 22(1).

Ihroni, T. O. (2001). Antropologi Hukum: Sebuah Bangsa Rampai. Yayasan Obor Indonesia.

Ismawati, \& Et.al. (2019). Implementasi UU Wakaf dalam Penyelesaian Sengketa Wakaf di Wilayah Pesisir Jawa Tengah. Jurnal MasalahMasalah Hukum, 48(4), 331-340.

Jamal, R. (2008). Hukum Perwakafan Kompilasi Hukum Islam Dalam Sorotan. Jurnal Ilmiah Al-Syir'ah, 6(1).

Komariah, U. (2014). Penyelesaian Sengketa Wakaf di Pengadilan Agama. Jurnal Hukum Dan Peradilan, 3(2).

Magnesi, H. A. (2018). Analisis Terhadap Sertifikasi dalam Sengketa Tanah Wakaf (Studi Kasus Mushola Nurun Nafi' di Jalan Kintelan Kelurahan Bendugan Kecamatan Gajah Mungkur Kota Bandung). Fakultas Syariah dan Hukum, Universitas Islam Negeri Walisongo. 
Manan, A. (2008). Aneka Masalah Hukum Perdata di Indonesia. Kencana.

Qohar, A. (2011). Tanya Jawab, Hukum Pembuktian dalam Teori dan Praktik. Pustaka Biru.

RI, D. A. (2007). Fiqih Wakaf. Direktorat Jenderal Bimbingan Masyarakat Islam. Sari, E. K. (2007). Pengantar Hukum Zakar dan Wakaf. Grasindo.

Siregar, I. (2012a). Penyelesaian Sengketa di Indonesia: Pendekatan Sejarah Sosial Hukum Islam. MIQOT: Jurnal Ilmu-Ilmu Keislaman, 13(1).

Siregar, I. (2012b). Penyelesaian Sengketa Wakaf di Indonesia. MIQOT, 36(1).

Suwaidi, A. (2011). Wakaf dan Penerapannya di Negara Muslim. Economic: Jurnal Ekomomi Dan Hukum Islam, 1(2), 14-33.

Usman, S. (1999). Hukum Perwakafan di Indonesia. Darul Ulum.

Zelania. (2017). Problematika Tanah Wakaf yang Tidak Memiliki Akta Ikrar Wakaf (Studi di Desa Kotway Kecamatan Buay Pemaca Kabupaten Ogan Komering Selatan). Institut Agama Islam Negeri Metro. 